\title{
Evolution and characterization of eggshell as a potential candidate of raw material
}

\section{(Evolução e caracterização da casca de ovo como potencial candidata de matéria-prima)}

\author{
T. Zaman ${ }^{1 *}$,Mst.S. Mostari ${ }^{1}$, Md.A.Al Mahmood ${ }^{1}$, Md.S. Rahman ${ }^{1}$ \\ ${ }^{I}$ Rajshahi University of Engineering \& Technology, Department of Glass \& Ceramic Engineering, \\ Rajshahi-6204, Bangladesh
}

\begin{abstract}
Characterization of both uncalcined and calcined eggshells was done in this work. Raw eggshells turned out as a good source of calcite phase. Calcined eggshells had a mixture of lime and portlandite phase. A significant impact of calcination temperature on the percentage of generated phases was observed. Qualitative as well as semi-quantitative phase analysis, morphological characterization and physical property estimation was done for the produced powder. The influence of synthesized raw material on soil stabilization and biomaterial formation was further assessed. The eggshell turned out as a potential source of raw material for various sectors. Keywords: eggshell, calcination, true density, plasticity index, hydroxyapatite.
\end{abstract}

\section{Resumo}

A caracterização de cascas de ovo não calcinada e calcinada foi feita neste trabalho. A casca de ovo mostrou-se uma boa fonte de fase de calcita. As cascas de ovo calcinadas apresentaram mistura de cal e fase portlandita. Observou-se impacto significativo da temperatura de calcinação na porcentagem das fases geradas. Foram realizadas análises de fase qualitativa e semiquantitativa, caracterização morfológica e determinação da propriedade física para o pó produzido. Foi avaliada a influência da matéria-prima sintetizada na estabilização do solo e na formação de biomaterial. A casca de ovo mostrou ser uma fonte potencial de matéria-prima para vários setores.

Palavras-chave: casca de ovo, calcinação, densidade real, índice de plasticidade, hidroxiapatita.

\section{INTRODUCTION}

Food wastes are found to be the origin of several health and environmental hitches. According to the Food and Agriculture Organization (FAO) of the United Nations, the worldwide direct economic cost of food waste was $\$ 750$ billion in 2013 [1] which is increasing tremendously. Almost all food wastes contain some sort of useful minerals. Hence, it is obligatory to find out an alternative route of valuable mineral extraction from these food wastes and overcome the high disposal costs and environmental concerns [2]. However, for the utilization of these organic food wastes having energy, water and mineral content, proper disposal of these are mandatory. Government regulations concerning landfills can lead to an economic stimulus to create value out of these wastes [3]. Among the various food wastes, eggshells have many bioactive compounds exhibiting high economic values. Eggshells are basically comprised of a network of protein fibers along with some mineral compounds like calcium carbonate $\left(\mathrm{CaCO}_{3}\right)$, magnesium carbonate $\left(\mathrm{MgCO}_{3}\right)$ and calcium phosphate $\left[\mathrm{Ca}_{3}\left(\mathrm{PO}_{4}\right)_{2}\right]$. A trace amount of sodium $\left(\mathrm{Na}^{+}\right)$, potassium $\left(\mathrm{K}^{+}\right)$, zinc $\left(\mathrm{Zn}^{2+}\right)$, manganese $\left(\mathrm{Mn}^{2+}\right)$, iron $\left(\mathrm{Fe}^{2+} / \mathrm{Fe}^{3+}\right)$ and copper $\left(\mathrm{Cu}^{2+}\right)$ have also been reported previously $[4,5]$. However, almost 94-96\% of an eggshell is reported as $\mathrm{CaCO}_{3}$ which is the major constituent of many manufacturing industries. A good quality eggshell might contain as high as $2.2-5.5 \mathrm{~g}$ of $\mathrm{CaCO}_{3}$ [6]. Consumption of eggshell as an affluent source of $\mathrm{CaCO}_{3}$ could solve both ecological and financial interest.

Since organic dyes generated from different industries are essentially responsible for the water pollution, waste water treatment is today's prime concern. Adsorption is one of the effective methods for the removal of dyes from water. Different types of adsorbents are used for this purpose. Literature survey revealed the expensive, complex synthetizations of adsorbents could be avoided by consuming waste eggshells [7,8]. Tri-calcium phosphate (TCP) and hydroxyapatite (HAP) are extensively studied biocompatible materials that can be prepared from natural calcium sources like eggshells, fish bones, sea shells, etc. [9-11]. Ceramic wall tiles are primarily composed of quartz, clays and different carbonates. The potential use of eggshells as ceramic raw material for tiles and sanitary sectors have also been reported earlier [12]. Another significant application of 
eggshells are as mineral fillers in thermoplastic materials like high density polyethylene (HDPE). Natural source of carbonates as a filler material have been adopted widely enhancing the rigidity, thermal stability and density of plastic materials [13]. Most of the construction failures are attributed to poor strength of soil. Stabilization of soil by the addition of lime, cement, bitumen, etc. is quite expensive. Eggshells could be a profitable replacement improving not only physical but also mechanical properties of soil [14, 15]. Recently, the utilization of natural sources from waste materials, i.e. eggshells, has been considered as a new trend for biodiesel production [16]. Investigations associated with the consumption of the eggshell waste as a renewable catalyst has already been mesmerized. Using eggshell wastes as raw materials for catalyst synthesis is a lucrative approach indeed [17]. Extraction of the bioactive compounds present in the eggshells would be beneficial for cosmetic and pharmaceutical industries. Moreover, eggshells could serve as a valuable and sustainable resource for the raw materials to make glass, glass-ceramic or ceramic products. Therefore, the present work contemplates on the extraction and characterization of one of the most easily accessible as well as useful source of raw material from eggshells and evaluates its beneficial applications.

\section{MATERIALS AND METHODS}

At first eggshells were collected as primary raw material from domestic sectors. The waste eggshells were cleaned thoroughly with cold water and dried naturally for seven days. After initial drying, the eggshells were kept in boiling water for $\sim 1 \mathrm{~h}$ to remove any unwanted substances. Meanwhile, the egg membranes were taken out from shells carefully. After boiling, eggshells were finally dried in an oven at $100{ }^{\circ} \mathrm{C}$ for $48 \mathrm{~h}$. Further, the dried eggshells were crushed in an attrition mill. The crudely crushed eggshells having $>6 \mathrm{~mm}$ particle size were taken for the next calcination step. Calcination was carried out in a muffle type furnace (Protherm PLF, Turkey). The temperature was varied from 800 to $1100{ }^{\circ} \mathrm{C}$ for a fixed soaking time of $2 \mathrm{~h}$. During calcination, the heating rate was kept at $3{ }^{\circ} \mathrm{C} / \mathrm{min}$ to ensure complete removal of carbon dioxide $\left(\mathrm{CO}_{2}\right)$. After calcination, obtained sample was roughly crushed and mixed in a mortar and pestle to get homogenous powder. Finally, the powder samples were taken for further characterization.

True density of the powder samples was measured using Quantchrome Gas Pycnometry (Ultrapyc 1200e, USA). Plasticity index (PI) was calculated adopting Pfefferkorn Plasticity Tester (PFEFF001, UK). Qualitative as well as semi-quantitative (S-Q) phase analysis for both uncalcined and calcined eggshells was carried out with X-ray diffractometer (XRD, Bruker AXS D8 Advance, Germany). Parameters were varied from 20 to $70^{\circ}$ with a scan speed of $0.03 \%$. Differential scanning calorimetry (DSC) was utilized for uncalcined eggshell powder by varying temperature from 30 to $600{ }^{\circ} \mathrm{C}$ at a rate of $10{ }^{\circ} \mathrm{C} / \mathrm{min}$ using Netzsch, DSC-204 F1 (Germany). The morphological characterization of the powder was done using a scanning electron microscope (SEM, Zeiss Evo-18, Germany). Next, the preparation of hydroxyapatite or HAP was done with the freshly synthesized $\mathrm{CaO}$ powder (calcined at $800{ }^{\circ} \mathrm{C}$ for 2 h). $35 \%$ phosphoric acid solution $\left(\mathrm{H}_{3} \mathrm{PO}_{4}\right)$ was consumed for this purpose. The solution $\mathrm{pH}$ was adjusted to $\sim 0.5$ with the help of ammonia $\left(\mathrm{NH}_{4} \mathrm{OH}\right)$ solution. The mixing of acid solution and calcined powder was done at an appropriate ratio. After mixing, the sample was dried in an oven by heating at $900{ }^{\circ} \mathrm{C}$ for $4 \mathrm{~h}$. Further analysis of the synthesized powder was done to evaluate its characteristics.

\section{RESULTS AND DISCUSSION}

XRD analysis: Fig. 1 shows the qualitative phase study of both uncalcined and calcined powders of eggshell. The analysis for uncalcined powder revealed the existence of thermodynamically stable calcite $\left(\mathrm{CaCO}_{3}\right)$ phase as a major component of the sample. All the characteristic peaks shown in Fig. 1a seemed to be well-fitted with $\mathrm{CaCO}_{3}$ demonstrating the fact of considerable hardness of the eggshell. Occurrence of more than $90 \% \mathrm{CaCO}_{3}$ having rhombohedral structure was achieved through this work. Although it is in line with some previous works $[6-9,18,19]$, Butcher and
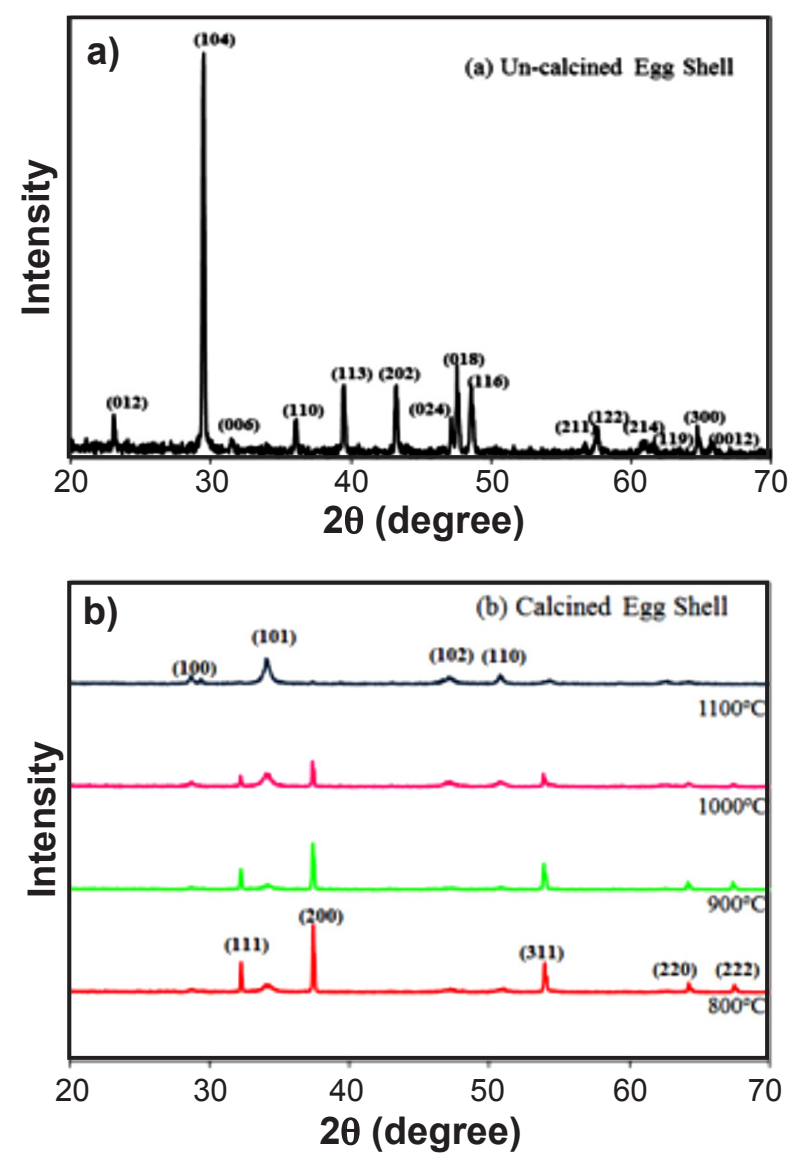

Figure 1: Room temperature X-ray diffraction patterns for uncalcined (a) and calcined (b) eggshell powders.

[Figura 1: Difratogramas de raios X à temperatura ambiente dos pós de casca de ovo não calcinado (a) e calcinado (b).] 
Miles reported much higher percentage of calcite in raw eggshells [20]. Attendance of other phases as confirmed by $\mathrm{S}-\mathrm{Q}$ data could illuminate this phenomenon. XRD patterns of the calcined powder shown in Fig. 1b contributed with some remarkable observations in our case. Essentially, the optimum calcination temperature of $\mathrm{CaCO}_{3}$ could vary with the purity of raw material (waste eggshells). Witoon [21] reported the synthesis temperature of $\mathrm{CaO}$ from uncalcined eggshells at $700{ }^{\circ} \mathrm{C}$. However, the calcination temperature was reported above $800{ }^{\circ} \mathrm{C}$ in some other papers [7, 13, 16]. Decomposition below $600{ }^{\circ} \mathrm{C}$ provided the incomplete removal of organic substances like membranes and proteins, as mentioned in [7]. Therefore, to study the consequences of calcination temperature, a wide range of temperature was chosen initially.

The semi-quantitative phase analysis acquired from XRD patterns showed the relative percent of different phases. Table I shows the percentage of phases present in the samples calcined at different temperature. According to the S-Q data, calcination at $800,900,1000$ and $1100{ }^{\circ} \mathrm{C}$ generated $87.8 \%, 77.2 \%, 43.3 \%$ and $5 \% \mathrm{CaO}$, respectively. The degree of crystallinity of $\mathrm{CaO}$ calcined at $800{ }^{\circ} \mathrm{C}$ was much higher than others which imply it as the appropriate temperature for the synthesis of $\mathrm{CaO}$ in this case. Moreover, appearance of $\mathrm{Ca}(\mathrm{OH})_{2}$ was perceptible for almost all temperatures. The prominent peaks for both $\mathrm{CaO}$ and $\mathrm{Ca}(\mathrm{OH})_{2}$ phase is marked in the patterns of 800 and 1100 ${ }^{\circ} \mathrm{C}$, respectively (Fig. 1b). The sequential transformation of $\mathrm{Ca}(\mathrm{OH})_{2}$ from $\mathrm{CaO}$ could be clearly witnessed from the patterns which could be enlightened by considering the reaction mechanism. The following decarbonation reaction occurs at calcination temperature:

$$
\mathrm{CaCO}_{3} \rightarrow \mathrm{CaO}+\mathrm{CO}_{2}
$$

Nevertheless, $\mathrm{CaO}$ transform into $\mathrm{Ca}(\mathrm{OH})_{2}$ upon exposure to atmosphere by the reaction:

$$
\mathrm{CaO}+\mathrm{H}_{2} \mathrm{O} \rightarrow \mathrm{Ca}(\mathrm{OH})_{2}
$$

Formation of $\mathrm{Ca}(\mathrm{OH})_{2}$ during the process of calcination is a very common incident and viewed by several researchers during synthesizing $\mathrm{CaO}$ [4-11]. Extreme hygroscopic nature of lime $(\mathrm{CaO})$ could end up with the formation of $\mathrm{Ca}(\mathrm{OH})_{2}$. It is to be noted that, an increasing trend in the formation of $\mathrm{Ca}(\mathrm{OH})_{2}$ was detected with calcination temperature and consequently calcination at $1100{ }^{\circ} \mathrm{C}$ generated the highest percentage of $\mathrm{Ca}(\mathrm{OH})_{2}(79.7 \%)$. Justification of the above statement could be attributed by the fact of high temperature decarbonation which stimulated the formation of $\mathrm{Ca}(\mathrm{OH})_{2}$ during atmospheric disclosure $[13,21]$. According to the concept of lime kinetic behavior diagram, lime calcined at $1100{ }^{\circ} \mathrm{C}$ shows greater reactivity than the lime generated below or above this temperature. The theory further states that low temperature $\left(<1100{ }^{\circ} \mathrm{C}\right)$ calcination could cause partial or incomplete decomposition, while thermal treatment above $1100{ }^{\circ} \mathrm{C}$ could lower the reactivity of particles via grain growth and densification process [1922]. As the reactivity of lime is nothing but the hydrational susceptibility, the $\mathrm{CaO}$ produced at $1100{ }^{\circ} \mathrm{C}$ should show highest hydration or slaking rate resulting in formation of greater percent of $\mathrm{Ca}(\mathrm{OH})_{2}$. The outcome of our work was in good agreement with this kinetic model.

Table I - Semi-quantitative analysis of powders calcined at different temperatures.

[Tabela I - Análise semiquantitativa de pós calcinados em diferentes temperaturas.]

\begin{tabular}{ccccc}
\hline Phase & $800{ }^{\circ} \mathrm{C}$ & $900{ }^{\circ} \mathrm{C}$ & $1000{ }^{\circ} \mathrm{C}$ & $1100{ }^{\circ} \mathrm{C}$ \\
\hline $\mathrm{CaO}$ & 87.8 & 77.2 & 43.3 & 5.0 \\
$\mathrm{Ca}(\mathrm{OH})_{2}$ & 12.2 & 22.8 & 56.7 & 79.7 \\
Others & - & - & - & 15.3 \\
\hline
\end{tabular}

True density measurement: the variation of true density of the calcined powder with calcination temperature is shown in Fig. 2. Sample calcined at $800{ }^{\circ} \mathrm{C}$ provided the highest density of all $\left(2.697 \mathrm{~g} / \mathrm{cm}^{3}\right)$, and the lowest density was

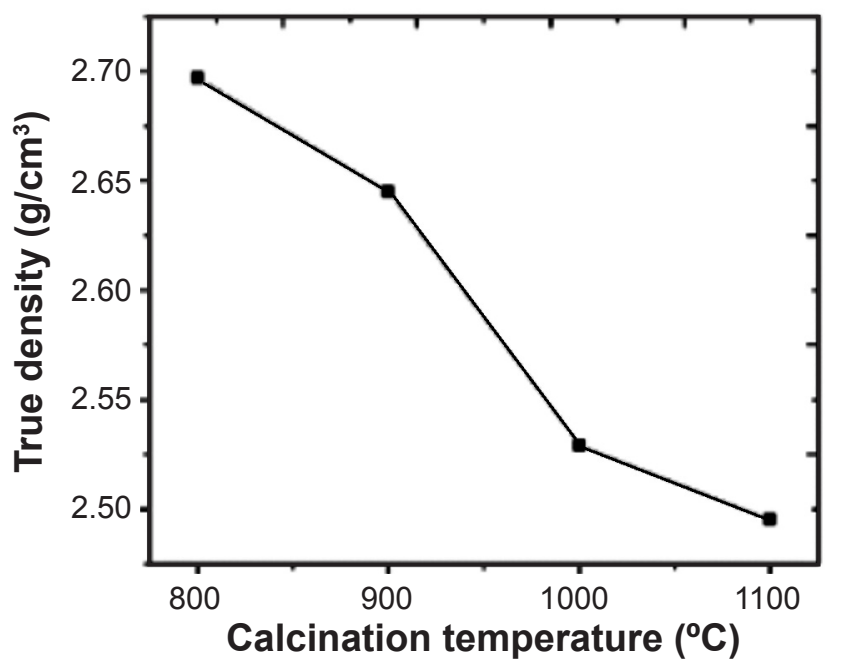

Figure 2: Variation of true density with calcination temperature. [Figura 2: Variação da densidade real com a temperatura de calcinação.]

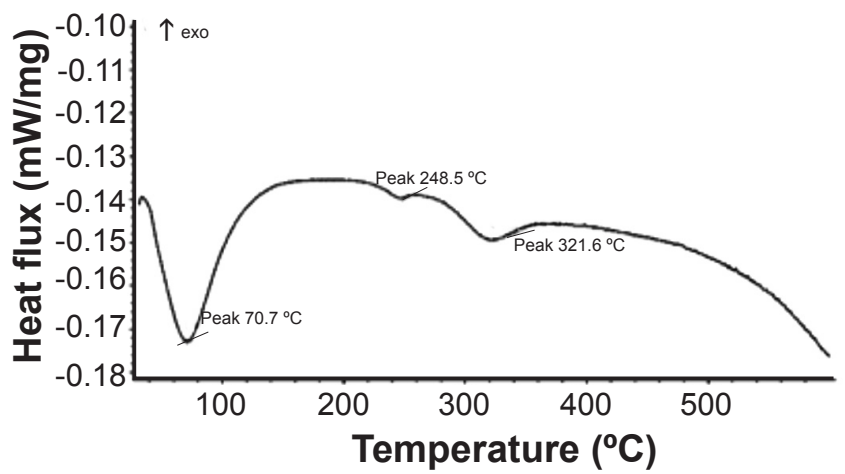

Figure 3: Thermal behavior (DSC) of uncalcined eggshell powder. [Figura 3: Comportamento térmico (DSC) do pó de casca de ovo não calcinado.] 

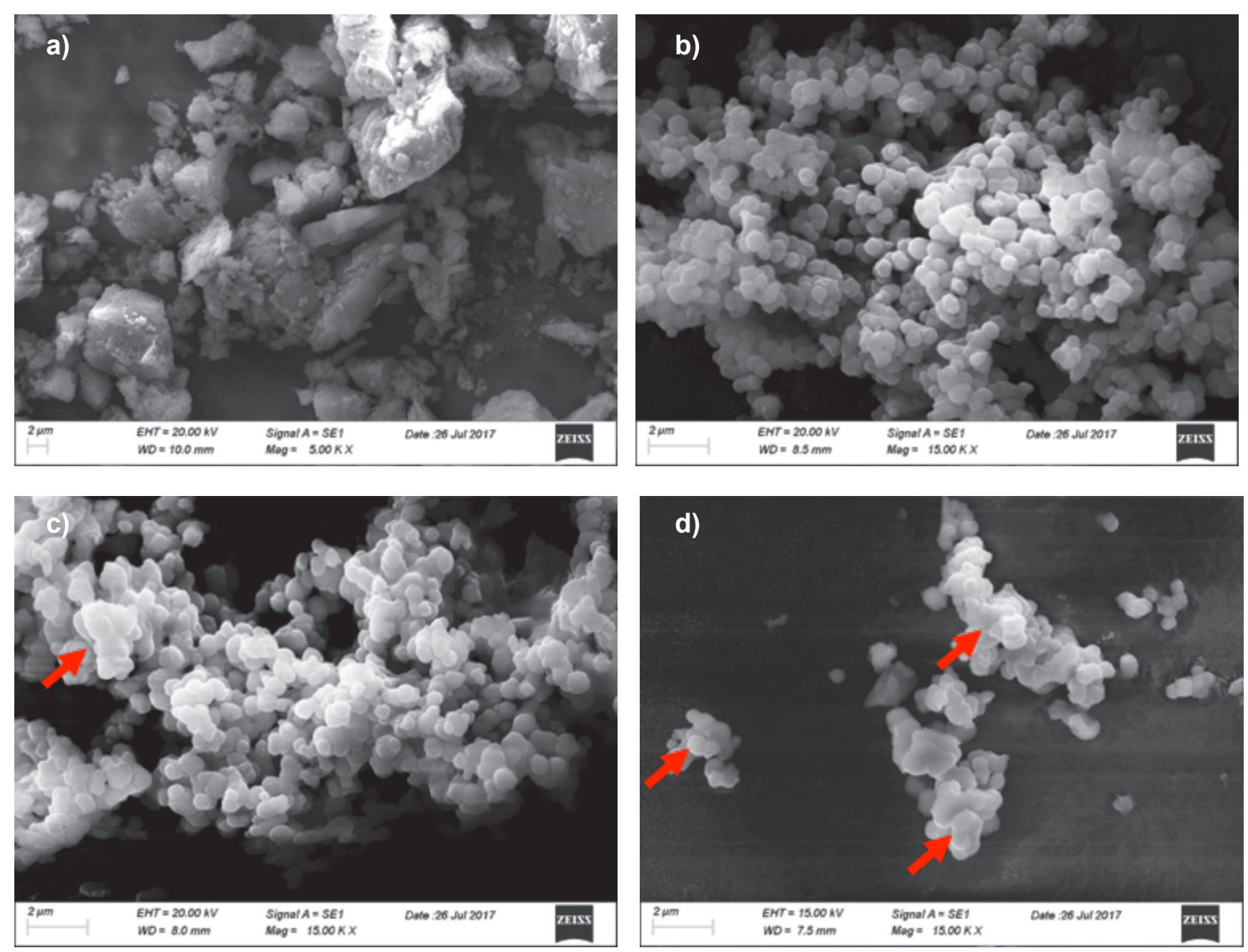

Figure 4: SEM micrographs of uncalcined (a) and calcined powders of eggshells at $800{ }^{\circ} \mathrm{C}(\mathrm{b}), 900{ }^{\circ} \mathrm{C}(\mathrm{c})$, and $1000{ }^{\circ} \mathrm{C}(\mathrm{d})$.

[Figura 4: Micrografias obtidas por microscopia eletrônica de varredura de pós de casca de ovo não calcinado (a) e calcinado em $800{ }^{\circ} \mathrm{C}$ (b), $900{ }^{\circ} \mathrm{C}(\mathrm{c})$ e $\left.1000^{\circ} \mathrm{C}(\mathrm{d}).\right]$

obtained for the sample calcined at $1100{ }^{\circ} \mathrm{C}\left(2.495 \mathrm{~g} / \mathrm{cm}^{3}\right)$. The event can be explained by the correspondence of relative quantity of different phases with calcination temperature. As the density of pure $\mathrm{CaO}\left(3.35 \mathrm{~g} / \mathrm{cm}^{3}\right)$ is considerably greater than $\mathrm{Ca}(\mathrm{OH})_{2}\left(2.21 \mathrm{~g} / \mathrm{cm}^{3}\right)$, relative percent of these two phases in the samples had perceptible impact on true density. This statement is also supported by the semi-quantitative analysis obtained via XRD.

DSC analysis: the thermal decomposition behavior of the uncalcined eggshell powder as shown in Fig. 3 elucidates the presence of three endothermic peaks. The first peak appeared at $\sim 70.7^{\circ} \mathrm{C}$ was due to the removal of physically adsorbed moisture. The peaks for the decomposition of organic substances like shell membranes and matrix protein were at $\sim 248.5$ and $\sim 321.6^{\circ} \mathrm{C}$. SEM micrographs: the micrographs of uncalcined and calcined eggshell are shown in Fig. 4. The morphology of uncalcined eggshell powder turned out to be irregular in shape. Occurrence of particles of various size was also noticeable in this case. On the other hand, nearly round shape particles of calcined eggshell powder were found for all the samples; however, with agglomeration

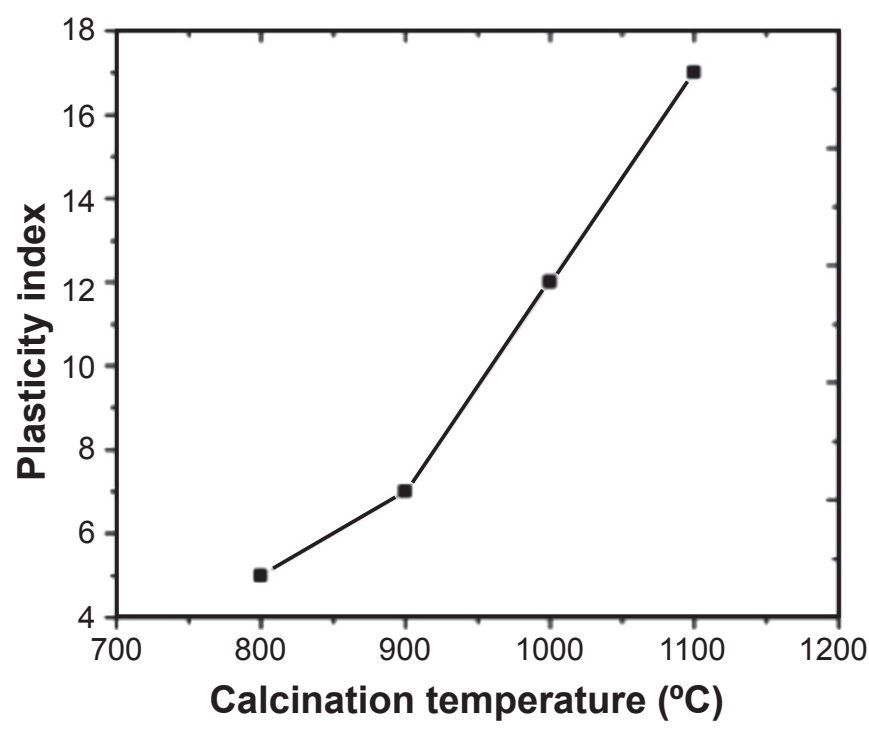

Figure 5: Variation of plasticity index (dimensionless) of soil with powder calcined at different temperatures.

[Figura 5: Variação do índice de plasticidade (adimensional) do solo com pó calcinado em diferentes temperaturas.] 
of particles attributed to a greater surface tension for the high temperature decarbonated samples. Clustering of particles with calcination temperature can be explained by the perception of interfacial energy as a function of particle superficial activity. Since absorption of moisture seemed to be augmented to a great extent for the high temperature calcined products, the formation of portlandite or $\mathrm{Ca}(\mathrm{OH})_{2}$ phase with hexagonal structure could not be avoided. As a matter of fact, particle agglomeration resulted (shown with red arrow marks in Fig. 4).

Plasticity measurement: the chronological change in plasticity index (PI) with the addition of powder calcined at different temperature is depicted in Fig. 5. 8\% calcined powder was mixed with soil for this purpose. Reasonable index of plasticity was found for the sample calcined above $900{ }^{\circ} \mathrm{C}$ signifying the fact of moderate plasticity of soil. Addition of $\mathrm{CaO}$ calcined at $800{ }^{\circ} \mathrm{C}$ reduced the PI value of soil. This statement can be indicated by the idea of soil stabilization [13, 14]. Accumulation of high concentration of lime $(\mathrm{CaO})$ could cause a reduction in plasticity of soil. With increasing amount of $\mathrm{Ca}(\mathrm{OH})_{2}$ in sample as evidenced previously, a slight increment in plasticity index was perceived. As declination of PI value is the indication of improvement in soil property [13], mixing $\mathrm{CaO}$ prepared at $800{ }^{\circ} \mathrm{C}$ amended the soil characteristics.

XRD of HAP: XRD pattern of the synthesized HAP powder is shown in Fig. 6. A good match with PDF 01079-5683 specifies that the suitable formation of HAP $\left[\mathrm{Ca}_{5}\left(\mathrm{PO}_{4}\right)_{3}(\mathrm{OH})\right]$ was possible through this work. However, identification of other secondary phases was beyond the scope of this work. SEM of HAP: morphological analysis of HAP powder is shown in Fig. 7, which reveals that fruitful synthesis of 0.1-0.4 $\mu \mathrm{m}$ particles was possible in this work. Round shape particles of HAP, having range of particle size confirmed the followed route as suitable chemical route of formulation. However, for synthesizing HAP nanoparticles, other parameters, like $\mathrm{pH}$ of solution, annealing temperature as well as soaking time, etc., need to be considered.

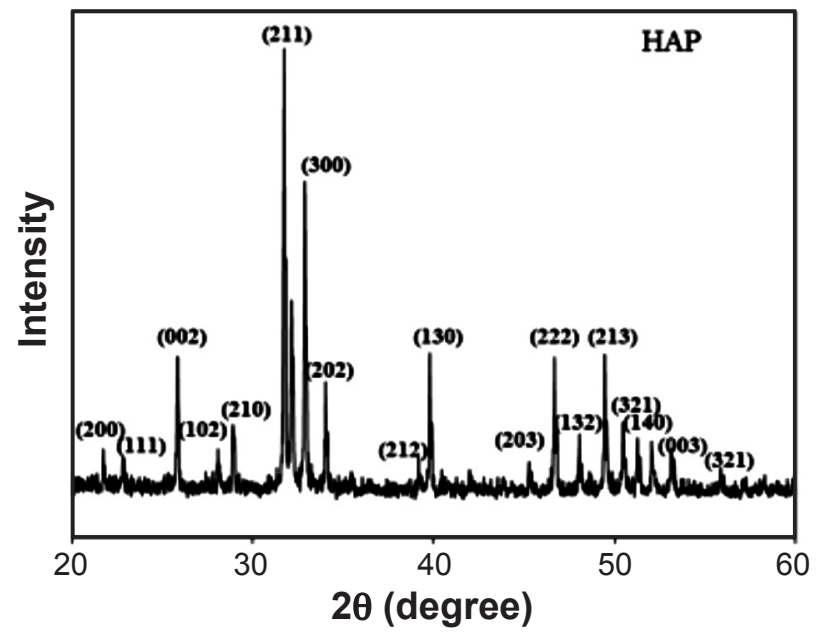

Figure 6: X-ray diffraction pattern for the synthesized HAP. [Figura 6: Difratogramas de raios X da hidroxiapatita sintetizada.]

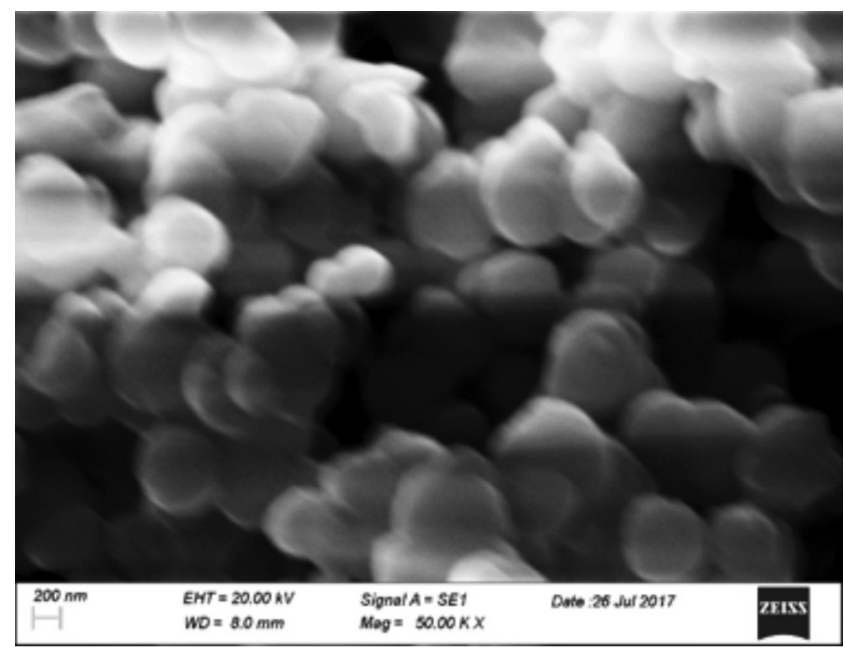

Figure 7: SEM image of HAP powder heat treated at $900{ }^{\circ} \mathrm{C}$ for $4 \mathrm{~h}$. [Figura 7: Micrografia obtida por microscopia eletrônica de varredura de pó de hidroxiapatita tratada a $900{ }^{\circ} \mathrm{C}$ por $4 \mathrm{~h}$.]

\section{CONCLUSIONS}

The work was focused not only on the extraction and characterization of $\mathrm{CaO}$ from raw eggshells but also its scope in various agricultural and technological sectors. It was revealed that both $\mathrm{CaO}$ and $\mathrm{Ca}(\mathrm{OH})_{2}$ formation is possible by controlling the process parameters. The occurrence of soil stabilization by the utilization of correct proportion of lime and synthetization of HAP by controlling parameters could be possible following the route. Hence, food wastes could be a prospective sector of interest.

\section{REFERENCES}

[1] "Food waste harms climate, water, land, and biodiversityNew FAO report", http://www.fao.org/news/story/en/ item/196220/icode/

[2] Eur. Comm. Report 2010-54, "Preparatory study on food waste across EU 27”, Eur. Comm. (2011).

[3] C.S.K. Lin, L.A. Pfaltzgraff, L. Herrero-Davila, E.B. Mubofu, S. Abderrahim, J.H. Clark, A.A. Koutinas, N. Kopsahelias, K. Stamatelatou, F. Dickson, S. Thankappan, Z. Mohamed, R. Brocklesby, R. Luque, Environ. Sci. 6 (2013) 426.

[4] K.A. Matori, M.M. Haslinawati, J. Basic Appl. Sci. 1, 3 (2009) 512.

[5] I.A. Rahman, H.I. Tijani, B.A. Mohammed, H. Saidu, H.Yusuf, M.N. Jibrin, S. Mohammed, J. Mater. 2014 (2014) 802467.

[6] V.L. Lechtanski, Inquiry-based experiments in chemistry, Oxford, New York (2000) 159.

[7] S. Chraibi, H. Moussout, F. Boukhlifi, H. Ahlafi, M. Alami, J. Encap. Adsorp. Sci. 6 (2016) 132.

[8] A.V. Borhade, A.S. Kale, Appl. Water Sci. 7 (2017) 4255. [9] T.S. Kanga, J.-Y. Kwakb, S.-J. Leea, J. Ceram. Proc. Res. 17, 9 (2016) 925.

[10] O.V. Sinitsyna, A.G. Veresov, E.S. Kovaleva, Y.V. 
Kolen'ko, V.I. Putlyaev, Y.D. Tretyakov, Russian Chem. Bull. 54, 1 (2005) 79.

[11] M.T. Hincke, Y. Nys, J. Gautron, K. Mann, A.B. Rodriguez-Navarro, M.D. McKee, Front. Biosci. 17 (2012) 1266.

[12] M.N. Freire, J.N.F. Holanda, Cerâmica 52 (2006) 240. [13] W. Sutapun, P. Pakdeechote, N. Suppakarn, Y. Ruksakulpiwat, Polym. Plast. Technol. Eng. 52 (2013) 1025. [14] M.M. Kumar, V.S. Tamilarasan, Int. J. Eng. Trends Technol. 11, 7 (2014) 319.

[15] M.I. Hossain, A. Khan, M.H. Haque, S.M. Ferooq, in Proc. Int. Conf. Mech. Eng. Renew. Energy, Chittagong, Bangladesh (2013).
[16] A. Buasri, N. Chaiyut, V. Loryuenyong, C. Wongweang, S. Khamsrisuk, Sustain. Energy 1, 2 (2013) 7.

[17] H.R. Fernandes, F. Andreola, L. Barbieri, I. Lancellotti, M.J. Pascual, J.M.F. Ferreira, Ceram. Int. 39 (2013) 9071.

[18] F. Guinotte, Y. Nys, Poult. Sci. 70 (1991) 583.

[19] W. Moffat, M.R.W. Walmsley, in $59^{\text {th }}$ Appita Conf., Auckland, New Zealand (2006).

[20] G.D. Butcher, R.D. Miles, "Concepts of eggshell quality”, Un. Florida, IFAS, VM69 (2015) 1.

[21] T. Witoon, Ceram. Int. 37 (2011) 3291.

[22] B. Engin, H. Demirtas, M. Eken, Radiat. Phys. Chem. 75 (2006) 268.

(Rec. 22/08/2017, Rev. 24/09/2017, 02/10/2017, Ac. 12/10/2017) 